\section{SOME MODIFICATIONS OF THE NORMAL} PHOTOGRAPH.

The amateur photographer begins with an ordinary camera, becomes dissatisfied and procures a better one, and irrequently proceeds in the same manner until he is satisfied that ne has secured the best instrument that can be obtained. It cuts the photographic image from the center to the edge of the plate with fidelity, and he derives great satisfaction in possessing as good a lens as can be made. But before very long he learns that a picture photographically perfect lacks a great deal in true artistic feeling and quality, and he begins to remedy the defects of the perfect lens by throwing the plate out of focus, or by using a larger stop, or both, and thus secures to some extent the broad effect that he has learned to admire.

In addition to following out these suggestions he may produce artistic effects in other ways which recommend themselves to the experimenter in photography. One of the simplest methods of obtaining a soft ethereal effect consists in interposing between the lens and the plate a piece of ground giass, glass coated with ground glass substitute, or ground glass celluloid placed at different distances from the plate, according to the effect desired. A very good scheme is to withdraw the slide from the plateholder and replace it by a slide of translucent ground glass celluloid, like that shown in one of the illustrations, taking care to exclude the en trance of light by changing the slides under the focusing cloth, the exposure being made through the ground glass celluloid. The resulting picture, whether portrait or landscape, is soft in outline, and is possessed of mellow lights and shades. The finer details of the photographic image are omitted, and the much-desired breadth is secured. If broader effects ground glass can be placed in the camera within or inside of the reversible back. Of course, the farther the glass or celluloid is removed from the sensitive plate the more details are omitted from the negative. If it is desired to show more of the detail than is possible with a translucent slide of the kind described a thin sheet of crystal glass of the size of the plate may be coated with ground glass substitute and placed in the holder along with the plate, with either the film or coated side out, according to the effect desired. The ground glass ce!luloid when placed either side out in contact with the sensitive film produces a desirable effect. If it is difficult to get ground glass celluloid a piece of fine, thin tracing paper may be secured by its corners to a thin piece of glass (an old negative glass, thoroughly cleaned will answer). The effect will be quite broad if the glass side is placed next the sensitive illm, and the negative will be very soft if the tissue paper is placed next the sensitive film. These interposed films absorb more or less of the light and necessitate an increased exposure, but the increase is very slight and can be determined only by experiment in each case. A lantern slide produced from a negative of this kind, if well colored, appears on the screen more like a painting than a photograph.

Another peculiar effect is secured by placing over the sensitive plate a thickness of fine, thin muslin stretched over a frame of common tin, or thin brass plate the frame being placed in the holder along with the plate. The muslin should be wet when mounted and secured to the frame by stratena or some other adhesive cement. Broader effects may be produced by removing the muslin screen to the reversible back.

Lantern slides printed from ordinary negatives through fine ground glass, or ground glass substitute, lend themselves beautifully to coloring, as they are broader an more like paintings than other colored slides.

A painter who dislikes to copy an ordinary photo-

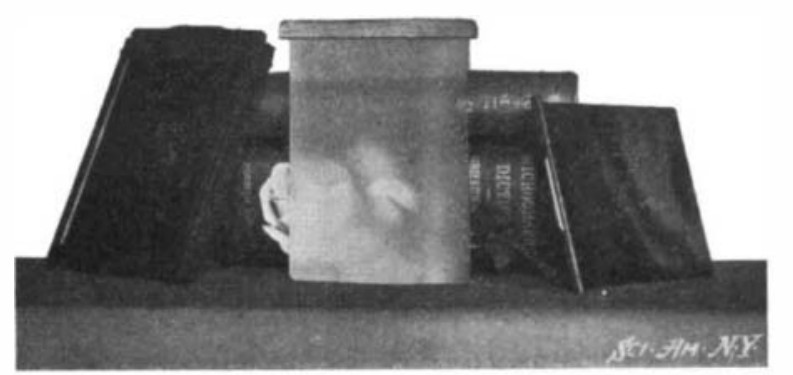

TRANSLUCENT SLIDE

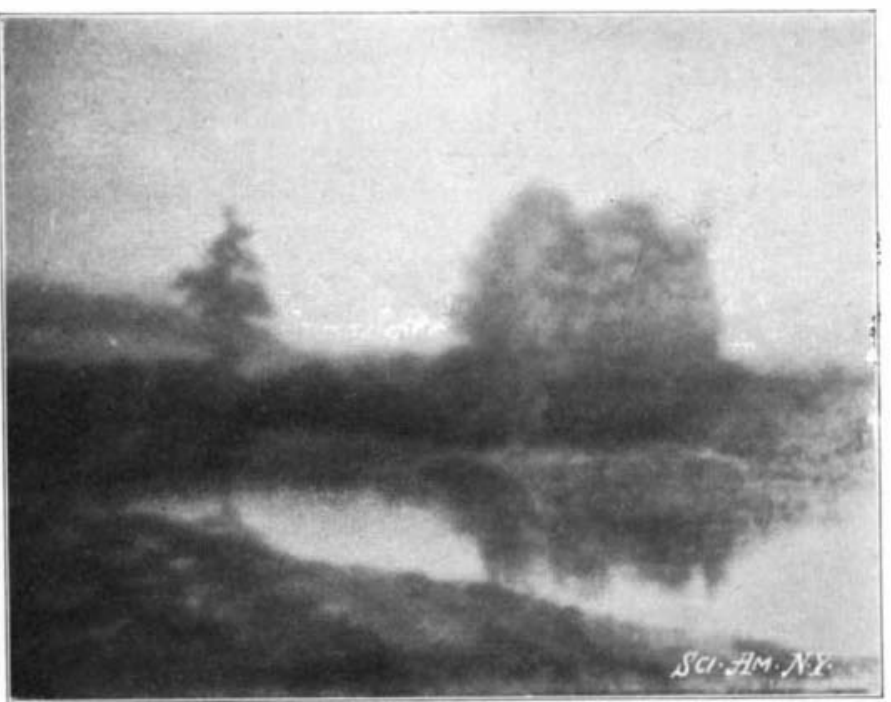

PHOTOGRAPH TAKEN WITH TRANSLUCENT SLIDE.

graph, on account of the difficulty of omitting detail, will find a copy of a good photograph taken through ground glass or tracing paper much more agreeable to follow than the photo with its many details. Halftones may also be copied in this way.

This may seem to the ultra-photographer, who takes the greatest interest in sharpness, depth and multitudinous detail, as a retrograde movement, tendin toward the degradation of photography, but the tru duced detail.

\section{HE CORONATION NAVAL REVIEW}

As far as the numbers and strength of the Britisi ships were concerned, the postponement of the coronation naval review detracted nothing from the splendo of the naval pageant of August 16; although the necessity for the witindrawal of most of the foreign warships caused the event to lose some of its inter- national character. The only foreign ships that were present at the review were the Japanese armored cruiser "Asama," of 9,700 tons displacement, and th 4,180-ton protected cruiser "Takasago," with the Italian ar'mored cruiser "Carl Alberto," of 6,500 tons, and the 4,100-ton Portuguese cruiser "Dom Carlos I." Outside of these four vessels the great fleet of 103 ships was marsinalled from the British navy, without withdrawing a single vessel from the Mediterranean or any ing a single vessel from foreign station or from the reserve fleet. The ships Defense fleet, and the Cruiser squadron, the last named being the latter-day representative of the famous Flying Squadron which was organized when Emperor William sent his famous message at the time of the Jamestown raid. Of the 107 vessels present, 4 were foreign ships, 20 were battleships, 24 were cruisers and the balance was made up of torpedo-boat destroyers, torpedo boats and other miscellaneous craft. The flect was anchored in five long lines which covered some 25 square miles of the sea, the line of visiting yachts being drawn up in position at the southeastern eno. The battleships line included such vessels as the "Prince George," "Hannibal," "Jupiter" and "Majestic," with the "Trafalgar," "Nile," "Royal Sovereign," and other vessels of from 12,000 to 14,900 tons displacement. The most modern and formidable of the cruisers was the armored "Sitli" of 14,000 tons and 23 knots speet. She was followed by the "Narcissus," "Galatea," "Niobe," "Crescent" (late flagship of the North Atlantic squadron) and the "Endymion." A onegun signal from the battleship "Royal Sovereign" at 2 o'clock announced the departure of the King in the new yacint "Victoria and Albert" from Cowes. The crews of the fleet at once manner shipped and simultaneously from over 100 vessels there thundered forth a salute of twenty-one suns, the firing being taken up by the shore batteries the fring beng taken up by the shore batteries quarter of an hour. The royal yacht then passed up and down the lines, and at 4 o'clock, at the finish of the review, as she came to her moorings escorted by a flotilia of torpedo-boat destroyers, another royal salute was fired. At night every vessel in the fleet at a given signal burst into a blaze of electric lights, the scheme of illumination consisting of a row of incandescent lights at the water line and at the upper deck, the outlining of the masts and funnels by similar lines of light. This was followed by an elaborate colored searchlight display by every vessel of the fleet, which formed the closing teature of the day's festivities.

In inie accounts of the review cabled over to this country there has been a great deal of misleading criticism $\mathrm{L}_{\mathrm{L}}$ which would lead the public to infer that the quality and efficiency of the British navy is in the inverse ratio of its nut the British navy is in the fact, the vessels engaged in the review were not by any means the most modern and formidable in the British navy, the battleships, for instance, and most of the cruisers havin ${ }_{2}$. been designed nearly a decado and a half ago. Hence, it is entirely misleading to compare the vessels present at the review with foreign vesels which have only just been turned out from the builders' yards. These battleships are of the same date as our "Oregon" and "Massachusetts." The

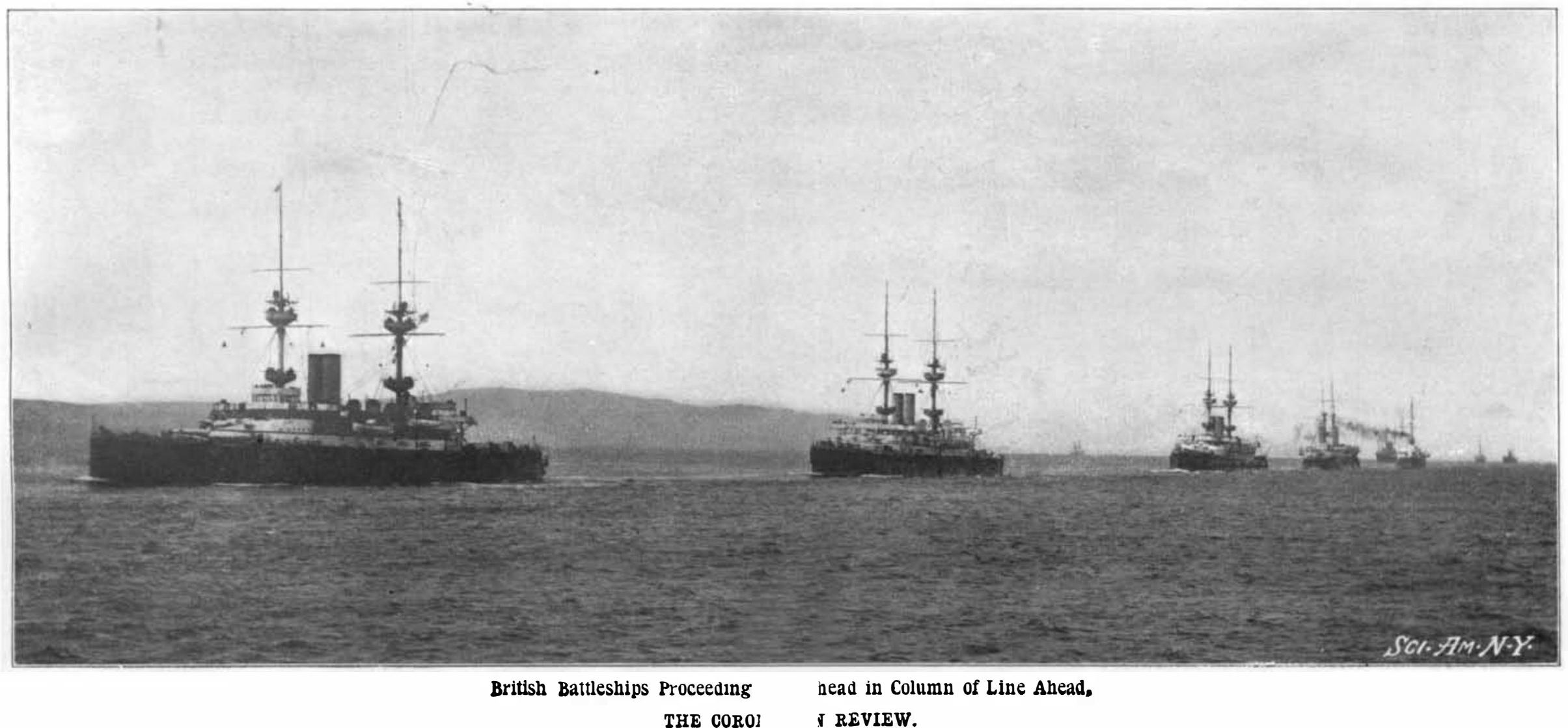

